\title{
Managing European Cross Border Cooperation Projects on Sustainability: A Focus on MESP Project
}

\author{
Corrado Schenone ${ }^{1, *}$, Margherita Marrè Brunenghi ${ }^{1}$, Ilaria Pittaluga ${ }^{1}$, Abdelrahman Hajar ${ }^{2}$, \\ Walid Kamali ${ }^{3}$, Federica Montaresi ${ }^{4}$, Mohammed Rasheed ${ }^{5,6}$, Abdallah Abdul Wahab ${ }^{3}$, \\ Yara El Moghrabi ${ }^{3}$, Riyad Manasrah ${ }^{5,6}$, Dima Merhaby ${ }^{2}$ and Lorenzo Montani ${ }^{4}$ \\ 1 Department of Mechanical Engineering, University of Genoa, 16145 Genoa, Italy; \\ margherita.marrebrunenghi@unige.it (M.M.B.); ilaria.pittaluga@unige.it (I.P.) \\ 2 Office exploitation of Port of Tripoli, 1301 Tripoli, Lebanon; abdelrahman_hajar@yahoo.com (A.H.); \\ merhaby.dima@hotmail.com (D.M.) \\ 3 Faculty of Engineering, Al-Manar University of Tripoli, 676 Tripoli, Lebanon; \\ walid.kamali@gmail.com (W.K.); wahab20aa@gmail.com (A.A.W.); yara.elmoghrabi@gmail.com (Y.E.M.) \\ 4 Port Authority of La Spezia, 19126 La Spezia, Italy; federica.montaresi@porto.laspezia.it (F.M.); \\ lorenzo.montani@porto.laspezia.it (L.M.) \\ 5 Marine Science Station, The University of Jordan, 77110 Irbid, Jordan; m.rasheed@ju.edu.jo (M.R.); \\ r.manasrah@ju.edu.jo (R.M.) \\ 6 Marine Science Station, The Yarmouk University, 21163 Irbid, Jordan \\ * Correspondence: corrado.schenone@unige.it; Tel.: +39-010-353-2577
}

Academic Editors: Francesco Asdrubali and Marc A. Rosen

Received: 28 September 2016; Accepted: 3 January 2017; Published: 13 January 2017

\begin{abstract}
International cooperation is a must to achieve the goal of sustainable development, since only through cross border actions' complex issues like environmental degradation can be faced. Supranational initiatives and shared objectives are the only path for getting a durable and effective green strategy, which transcends boundaries or governments and fosters a common effort for sustainability through networking. The European Neighborhood and Partnership Instrument (ENPI) aims at reinforcing cooperation between the European Union (EU) and partner countries' regions placed along the shores of the Mediterranean Sea. To this extent, MESP (Managing the Environmental Sustainability of Ports for a durable development) can be considered as a typical cross border cooperation project, willing to create a sustainable environmental management of port in northern and southern shores of the Mediterranean basin. This has been achieved through the development of specific guidelines towards environmental sustainability and the collection of common tools, methodologies, good practices and innovations focused on pollution reduction that can be replicated in Mediterranean ports and further. This was possible through the creation of a strong cooperation network and long-lasting collaborations among partners and stakeholders such as harbour cities, port authorities, universities, research centres and scientific skills.
\end{abstract}

Keywords: decentralized cooperation; ENPI CBCMED Program EU Projects; management; EU policy for sustainability

\section{Introduction}

In order to ensure a better quality of life for current and future generations, the EU developed the Sustainable Development Strategy (EU SDS) as the overarching policy framework for all Union policies and strategies. Thanks to short- and long-term objectives, it offers a wide range of common recommendations, key factors and visions regarding local and global actions on social, economic and environmental issues. With reference to the latter, in particular, the EU SDS aims to reduce the 
degradation eco-systems, crucial for guaranteeing a high quality of life, by strengthening the efforts for environmental protection [1-3].

Concerning maritime issues, at the regional level, attention has been paid to the so-called "Barcelona system" [4] consisting of the Convention for the Protection of the Marine Environment and the Coastal Region of the Mediterranean and its various protocols, respectively, dealing with dumping, pollution from ships, land-based pollution, specially protected areas and biodiversity, offshore activities and hazardous waste and, notably, integrated coastal zone management. The Barcelona Convention itself aims at ensuring an active cooperation among its contracting parties on a wide range of issues relevant to the protection of the Mediterranean marine and coastal environment while boosting regional and national plans to achieve sustainable development. In particular, it promotes the integrated management of the coastal zones taking into account the protection of areas of ecological landscape interest and the rational use of national resources.

A key operational tool for sustainable marine governance is certainly represented by Marine Spatial Planning [5] in order to implement the Ecosystem-Based Management approach (EBM) [6-8], provided by EU 2007 Integrated Maritime Policy (IMP) [9,10] and EU 2008 Marine Strategy Framework Directive (MSFD) objectives [11]. To this extent, in order for Member States to adequately contribute to this key strategy, according to their responsibilities and capabilities, EU promotes international programmes as the main tool to develop best practices to be locally applied [12,13].

The promotion of environmental sustainability at the Mediterranean basin level is one of the main priorities of the Operational Programme ENPI CBC MED (European Neighborhood and Partnership Instrument multilateral Cross-Border Cooperation "Mediterranean Sea Basin") [14] by dealing with the Mediterranean Countries' common challenges through a harmonious cooperation process. Among the various granted ENPI CBC MED projects, "MESP" (Managing the Environmental Sustainability of Ports for a durable development) [15] will be hereinafter analyzed, as a good example of EU sustainable project management. Moreover, MESP being a cross border cooperation project, the governance resulted in being more complex while being enriching with respect to other kind of EU funded projects, as deeply analyzed in the following.

This project aims to decrease pollution levels concerning air, noise and water deriving from port activities and give back to citizens, tourists and workers a healthier and more usable environment. During 36 months, the "status quo" of ports in northern and southern parts of the Mediterranean basin was analyzed, and a guideline on best practices, methodologies and measurement assessment for environmental sustainability of ports was elaborated on with the aim of being shared and replicated by Mediterranean ports.

The aim of this paper is to present and analyze the various managing practices successfully followed during the implementation of the project in order both to capitalize on them and to pave the way for their replication in other projects. To this extent, this paper will highlight:

- how the project was managed, responsibilities distributed and how the partners collaborated among them and with the Applicant to implement the activities of the project;

- the communication plan and the dissemination initiatives realized [16];

- the innovation characterizing the project and the actions to be considered as good practices to be replicated;

- the right way to capitalize the project, the resulted benefits and the Road map that could be drawn for future projects.

\section{Setting the Scene: Management of the Project Structure}

In the following, an overview on partnership and organizational structure of the project will be presented through a detailed description of project management strategies. It seems crucial for the success of a project to clearly define, since the beginning, the best possible partnership together with a 
correct and strong management approach, to implement the required technical activities in time and to guarantee the replicability of the project for a similar port context.

\subsection{Partnership}

MESP project has been able to promote environmental sustainability in the Mediterranean, thanks to a partnership composed of key actors in the field of environmental protection with a high level of heterogeneous expertise on environmental sustainability, pollution phenomena, and, most of all, the capability to enrich the state-of-the-art with the experience of different port contexts. The choice of MESP members was strongly connected to each partner's skills and experiences in environmental pollution thematic.

In fact, the partnership is composed of either academics, with strong experiences and competences, and port authorities and agencies, carrying their knowledge and awareness on issues concerning port realities and related activities. In this way, the presence within the partnership of universities and stakeholders assure a great level of accuracy and entirety to the project by directly applying the theoretical knowledge to the real harbour context. Moreover, the multidisciplinary approach for the three sectors of air, noise and water, permitted to have a broader vision of the port scenario, allow for optimizing MESP project activities.

MESP project has been implemented by six partners from four countries both from the northern and southern parts of the Mediterranean basin: Italy, Greece, Lebanon and Jordan. The partnership is composed of: the Mechanical Engineering Department (DIME) of the University of Genoa, Italy (as the Applicant Beneficiary), the Physical Oceanography Marine Science Station (MSS) from the University of Jordan, Aqaba, Jordan, the Port Authority of La Spezia, Italy, the Al-Manar University of Tripoli (MUT), Lebanon, the Department of Environment and Sustainable Development from the Patras Municipal Enterprise for Planning and Development S.A. (ADEP), Greece and the Exploitation Office of Port of Tripoli (OEPT), Lebanon (Figure 1).

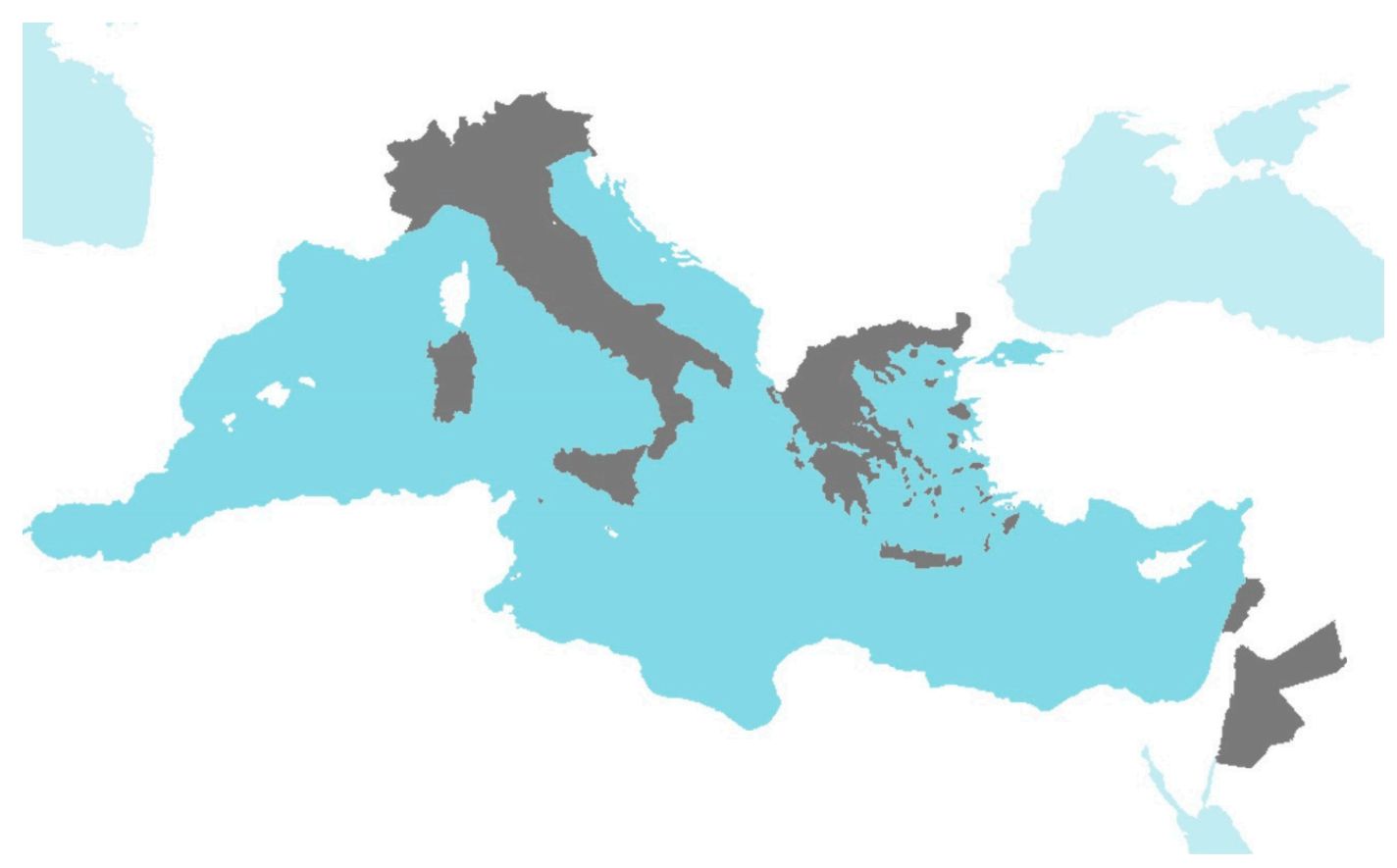

Figure 1. MESP partnership countries within the Mediterranean Basin area.

In addition, two more associate partners worked with the partnership: Jordan Environmental Society (JES) Aqaba, Jordan and Urban Community of Al-Fayhaa (UCF), Tripoli, Lebanon, playing an important role in the implementation of the project. Their added value consisted of upgrading training 
capacities in the field of environmental management together with supporting local partners in the implementation of the project. To this extent, UCF gave an institutional and operative support to the pilot project in Tripoli by involving the urban community, strongly affirming the interest of the entire territory for the project results. In the same way, JES supported MESP in Jordan with an awareness campaign for the public and governmental sectors regarding the importance of the environment as well the impact of the project.

The complex realities of ports include several different activities and various actors that need to be strongly involved in an effective management in the harbor context. Therefore, MESP collaborated with several organizations and created durable collaboration agreements with a wide range of different stakeholders, such as the Aqaba Special Economic Zone Area (ASEZA), the Aqaba Container Terminal (ACT), the Regional Agency for the Environment Protection in Liguria Region (ARPAL, Agenzia Regionale per la Protezione Ambientale) and the International Centre on Evironemntal Monitoring (CIMA, Centro Internazionale in Monitoraggio Ambientale) Foundation.

\subsection{Organizational Structure of the Project}

An overview of the management structure, setting of objectives and organization of technical activities will follow, enhancing MESP partnership efforts in building effective teams and methodologies.

\subsubsection{Management Organization}

MESP was equipped with a strong managerial level realized through integrating the Applicant with the partnership in four committees covering all aspects of the project, helping in the definition of each partner's responsibility and involvement in project activities, technical and operative coordination roles from the beginning. In particular:

- A Steering Committee, composed of the project coordinators of each partner and coordinated by the applicant. This group met at least once per year (during each project meeting) and transmitted to the whole partnership decisions and indications. Moreover, it supervised all the performed activities, time plan, final budget, reports and any occurring problem within project lifetimes.

- A Technical Committee, composed of one expert from each partner, organized in three Working groups, one for each area of interest (air [17-21], noise [19-26] and water [27-29]). This group has been involved in the decisional phases, particularly during the crucial phases of the design and implementation of project activities and interventions.

- A Scientific Advisory Committee, composed of one external expert for each environmental sector (air, noise and water), recruited outside the projects, in virtue of their competence and experience in validating outputs and project results.

- A Project Financial Committee, composed of the financial manager of each partner and coordinated by the Applicant Final Manager, which discussed any financial issues, prepared each periodic report, each variation to the budget and the final report to be sent to the ENPI CBC MED Joint Technical Secretariat (JTS) and Joint Managing Authority (JMA).

The MESP organizational structure, interrelationships, responsibilities and partners' contributions are described in Figure 2.

The project phases have been developed by three Working Groups (WGs) [30-32], one for each environmental sector (air, noise and water). The aim of WGs is to deal with the environmental problems that affect port context. They worked in parallel on the development of MESP activities, with some superposition when faced with common pollution reduction approaches. The WGs consisted of experts coming from different partner structures, based on his own expertise and skills. 


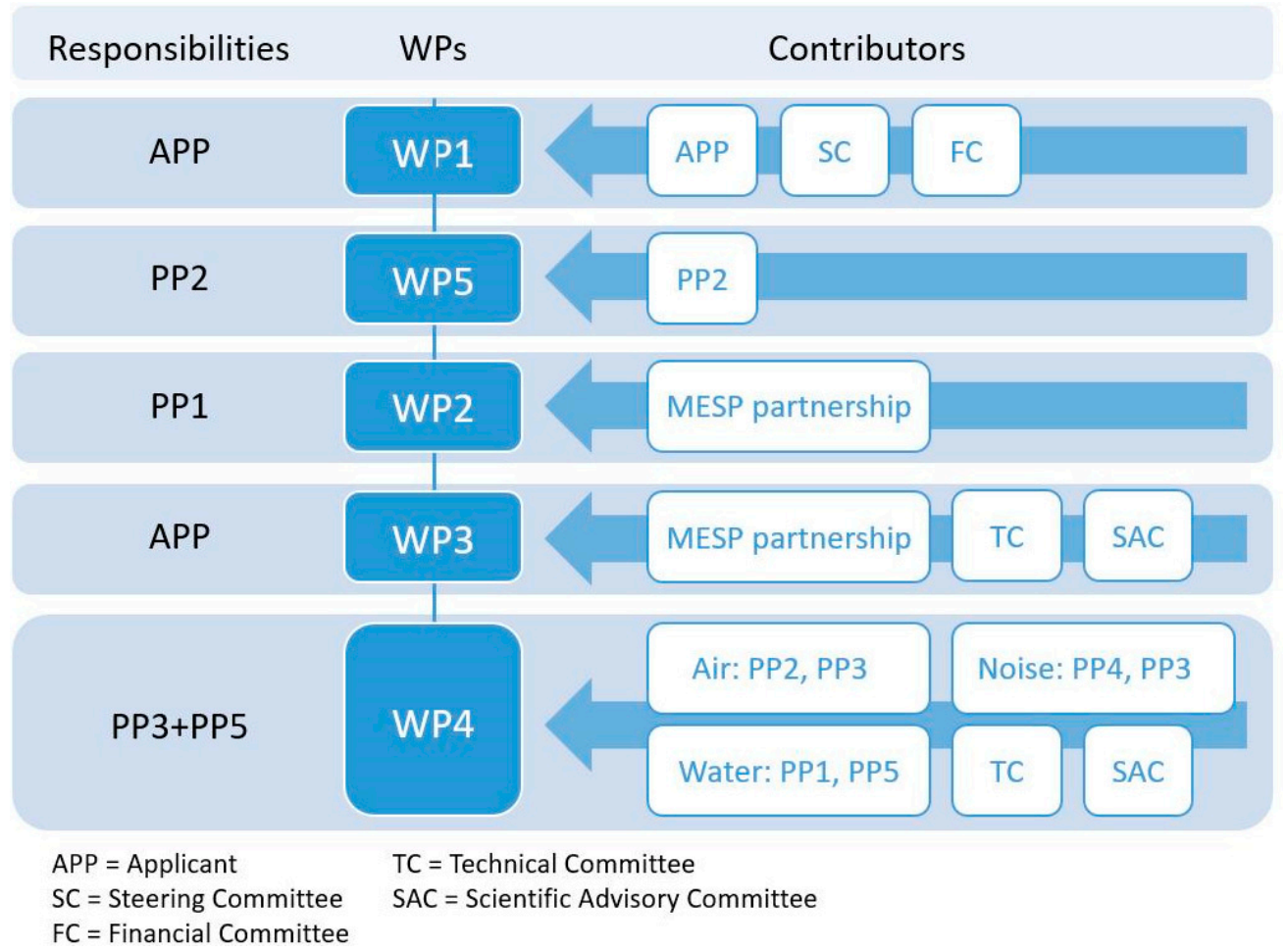

Figure 2. MESP organizational structure.

\subsubsection{Setting of Objectives}

MESP aims to reach three main long-term objectives, such as: (i) the creation of a long-lasting cooperation network among partners; (ii) the formulation of a common regulatory approach for the durable pollution management in ports; and (iii) the elaboration on standard guidelines to a common approach for sustainable pollution control in Mediterranean ports.

The general objective of MESP project [33] was set to guarantee the environmental sustainability of port activities and a high level of life quality in the nearby surrounding urban areas. The environment was taken into consideration under three main sectors strongly characterizing port areas: water, noise and air. The project aimed to decrease pollution levels deriving from port activities and give back to citizens, tourists and workers a healthier and usable environment. This was possible by providing method, procedures and practices easily applicable on both sides of the Mediterranean Sea, allowing for valuing and improving the environmental sustainability of ports. These actions aim to support management port authorities and infrastructures' users in reaching a higher level of sustainability and in decreasing the pollution levels.

\subsubsection{Management of Technical Activities}

MESP project proposed to carry out structured activities in an organic way and articulated in five Working Packages (WPs) as shown in Figure 3. WP1 on Coordination and Management and WP5 on Dissemination and Communication are meant to be crosscutting activities with technical interventions for the whole duration of the project implementation. Indeed, the real core of MESP lied in the three Work Packages "Knowledge sharing" (WP2), "Tool's implementation" (WP3) and "Pilot Projects" (WP4), where the scientific and technical activities have been developed.

- WP1 "Coordination and Management", aiming to ensure the correct implementation of the project, the correct level of expenditures, the organization of periodic meetings, the coordination of the partnership with respect to common objectives and the monitoring of requested outputs from JMA. 
- WP2 "Knowledge sharing", planning to collect data from each partner, using available experience and resources, in order to set the state-of-the-art at the international level about air, water and noise pollution. All data have been evaluated from different points of view such as legislation, management tools, technologies, and the most significant international experiences in the matter of study.

- WP3 “Tool's implementation", outlining a crucial phase of the project. In fact, all collected and shared information, methodologies, technologies and practices outlined in WP2 represented the basis for the definition of a specific methodological approach for the sustainable management of ports. In this way, in order to define the starting point for the build-up of the guidelines, a detailed study on real port contexts and surrounding urban areas appeared to be significant. Hence, specific analysis of the four MESP port territorial areas (Aqaba, La Spezia, Tripoli and Patras) have been conducted, collecting information particularly on trade, logistics, transport, mobility and future territorial planning. All this led to the final outcomes of WP3, the "Roadmap on Sustainability Criteria: Guidelines for Port Environmental Management", a simple and easy tool addressed to professional figures of the Mediterranean basin port public administrations, offering best-practice approaches to a sustainable management of harbors.

- WP4 "Pilot projects", representing the technical core of project activity. The aim was to validate, through pilot projects, the content developed in WP3. To this extent, three demo interventions, one for each thematic, have been implemented in MESP ports (Aqaba on water, La Spezia on air and Patras on noise). In order to assess if a common pollution reduction approach implemented in two or more environmental sectors can improve results or hinder other outcomes, pilot projects on air, noise and water have been implemented in the port of Tripoli, allowing for evaluating possible intervention influences. The flowchart of the technical Work Packages' different tasks is shown in Figure 4.

- WP5 "Dissemination and Communication", containing the correct methodology for a good project implementation and for an efficient dissemination of project results. Within the partnership, the efficacy of activities has been guaranteed by a constant and efficient support of dynamic dissemination actions and easily accessible tools. For what concerns external dissemination, it is worth noting that it seems crucial to clearly transfer project targets and results in order to raise awareness among citizens, local authorities and stakeholders on pollution abatement in ports, affecting the natural and urban environment.

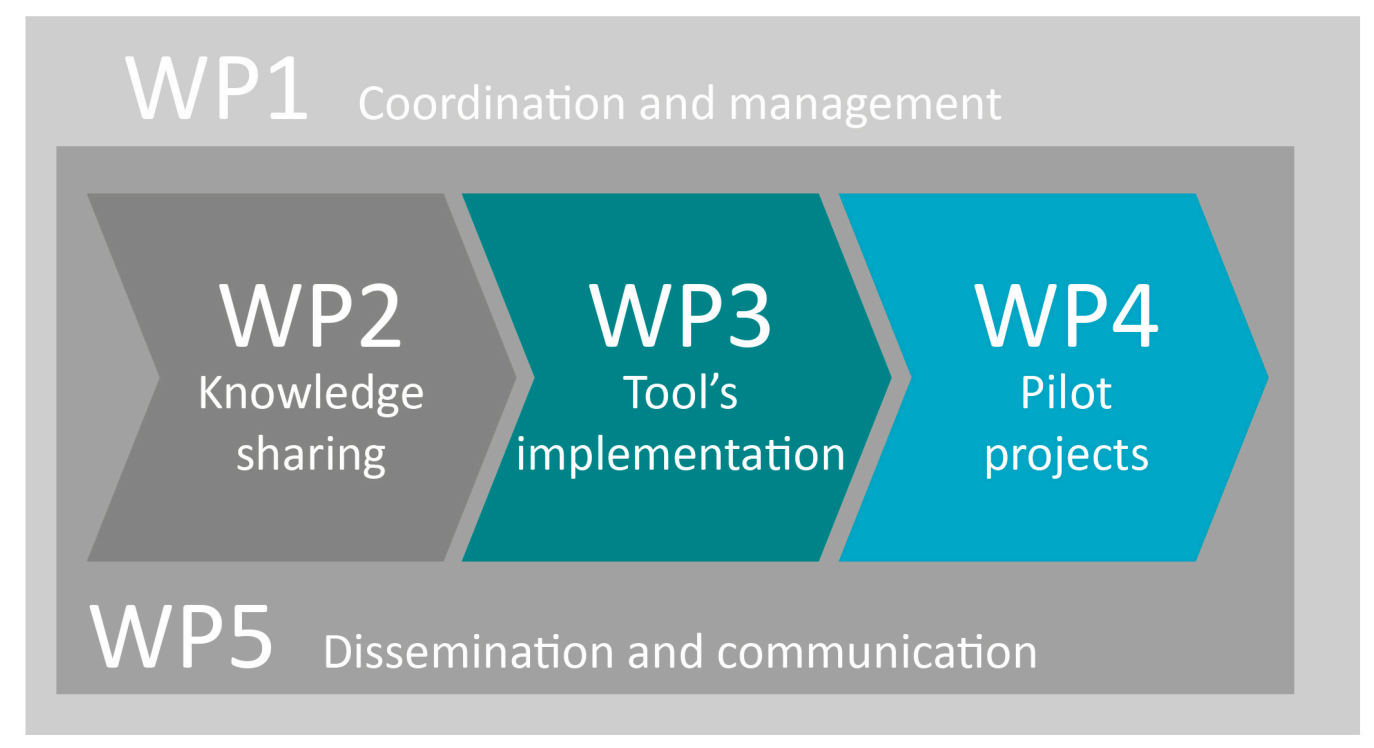

Figure 3. Schematic overview of the MESP work packages. 


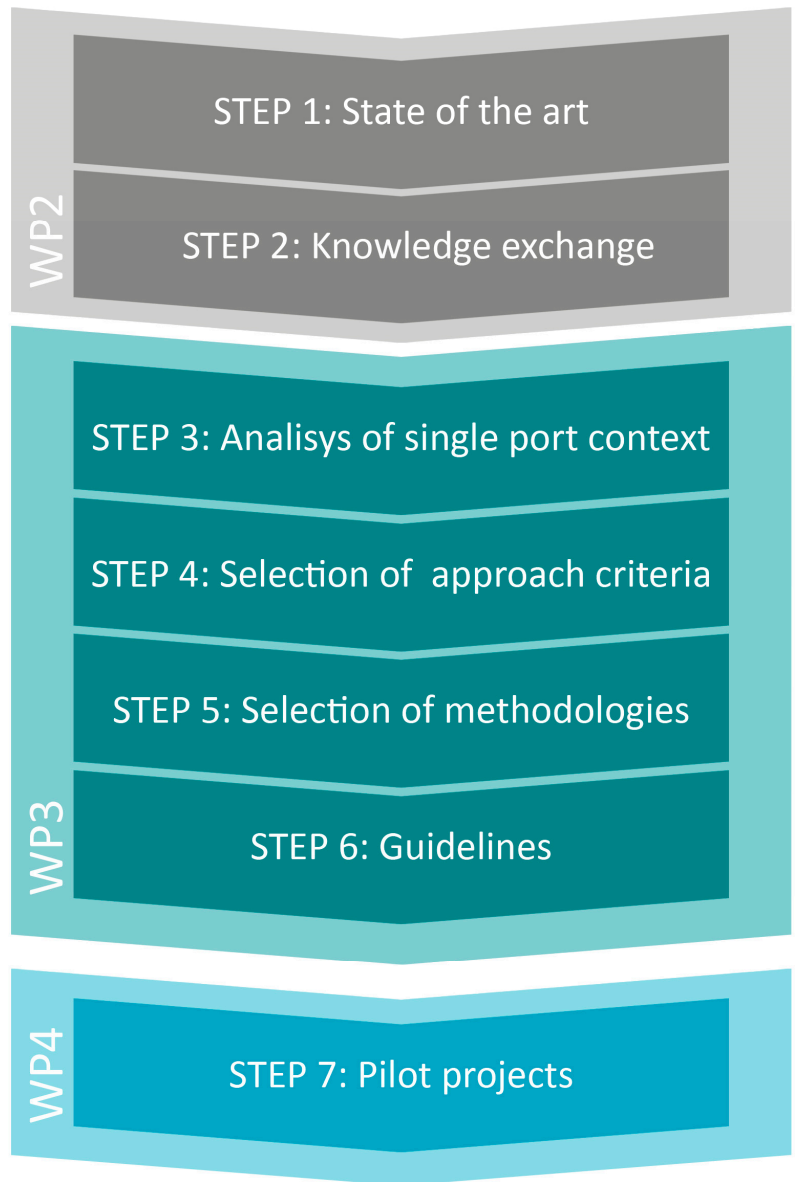

Figure 4. Flowchart of the MESP main actions.

\section{MESP Implementation Approach for Sustainable Development}

The abovementioned structure of the project allowed the partnership to proceed with the implementation of the activities foreseen in a continuous and fruitful way. In order to monitor the efficacy of the implementation of the project, performance criteria and indicators are considered among the best and most used tools, able to determine and describe the achievement of targeted goals. Namely, a Key Performance Indicator (KPI) [34-36] is a quantified gauge used to evaluate the progress status of an activity in reaching its target goals. According to different needs, KPIs can be chosen in strict relation to each reality, performance criteria and different objectives.

In European Project management, in particular, the most used KPIs are represented by:

- General indicators for the activity implementation (quantitative)

- Indicators on the project outcome (qualitative)

- Financial Indicators, evaluating the cash flow (quantitative)

- Time indicators (quantitative)

Relating to the ENPI CBCMED Programme, these KPIs have been measured on a time schedule basis every six months, allowing the Applicants to adequately check and evaluate their project progress and update the JMA on it. Two tools have been provided in order to monitor either the project management or the technical implementation of activities foreseen. The former, the Action Plan, included all listed activities divided by each semesters and had been updated several times throughout the duration of the project. The latter, the Logical Framework, contained all technical quantitative indicators specifically tailored for MESP project activities, expected results and their overall and specific objectives. 
Moreover, a large number of general Programme indicators, given by the JMA, have been measured in the final phase of the project, evaluating specifically:

- the achievement of ENPI CBCMED Programme objectives and goals, such as the common approaches or initiatives developed and achieved, the cross border networks created, etc.;

- the capability of the partnership in communicating and disseminating the project and the Programme, through events, workshops, scientific publications, etc.;

- the impact of project interventions within the related topic (e.g., MESP in reducing the environmental pollution in ports).

In the following, a detailed description of technical, administrative and communication management will be provided.

\subsection{Technical Management}

As specified in Section 2.1, a multidisciplinary team was engaged for the implementation of the project, combining the expertise in engineering, environmental sustainability, decentralized cooperation, and EU projects.

Although starting with different experiences and little common ground, the common objective of the sustainability of port management allowed the partnership to exploit the multidisciplinary competences in order to analyze and discuss common issues from different points of view. This was certainly a project key factor that contributed to providing a great added value for the activities, allowing for finding common solutions to different challenges. Moreover, plenary meetings were revealed to be crucial, particularly referring to pilot projects. In each city, a meticulous port visit has been organized as an important occasion to share knowledge and best practices on the different approaches in activities, technologies, management and logistics. This has led to fruitful discussion and analysis to set the forthcoming pilot project design and implementation interventions.

In order to best perform project activities within port areas, it has been necessary for each port to sign collaboration agreements with local players on the environmental platform, port stakeholders, environmental agencies, municipalities and related local EU projects. This permitted a better exploitation of local networks and of available economic and equipment resources.

To ensure the environmental sustainability aimed for by the MESP project after the end of the activities, all involved ports decided to continue the monitoring campaigns using the infrastructures, facilities equipment and tools funded by the project. Furthermore, Tripoli and Patras Ports are currently under the process of the ISO 9001:2015 [37] for quality management system and ISO 14001:2015 for environmental management system for the [38]. As an academic institution, MUT will build further activities based on MESP data within its Civil Engineering curriculum. The equipment purchased through the MESP project will be used in environmental engineering laboratory classes, or environment classes, where students are trained to use equipment as learned in testing procedures and measuring in the field.

The Scientific Advisory Committee played an important role throughout the whole duration of the MESP project. In fact, the three members, one for each sector, have been involved in the meetings and have expressed their opinion on the choice of equipment, measurement campaigns and final technical reports. Their added technical contribution gave a scientific value to all performed processes and activities.

In the following, the main results from the four pilot projects are summarized in Table 1. 
Table 1. MESP (Managing the Environmental Sustainability of Ports for a durable development) project main results.

\begin{tabular}{|c|c|c|c|c|}
\hline & Location & Interventions & Impact as Results & Stakeholder Involved \\
\hline \multirow[t]{2}{*}{ AIR } & La Spezia (Italy) & $\begin{array}{l}\text { Treatment of Marina del Canaletto road (inside port } \\
\text { area) with a biofix, able to "incorporate" particles and } \\
\text { limit the resuspension of air pollutants in the air }\end{array}$ & $\begin{array}{l}\text { Decrease in the component } \mathrm{PM}_{10} \\
\text { average evaluated of } 17 \%\end{array}$ & $\begin{array}{l}\text { ARPAL Liguria, CIMA } \\
\text { Foundation, EUROVIX S.p.A., } \\
\text { La Spezia Container Terminal }\end{array}$ \\
\hline & Tripoli (Lebanon) & $\begin{array}{l}\text { Purchase and constant use of a road sweeper in port } \\
\text { roads and quays. } \\
\text { Regular control of cranes and forklifts }\end{array}$ & $\begin{array}{l}\text { Reduction of air pollutants and dust } \\
\text { in the port and the surrounding areas; } \\
\text { Establishment of an environmental } \\
\text { port office. }\end{array}$ & $\begin{array}{l}\text { Balamand University, } \\
\text { Municipality of Tripoli }\end{array}$ \\
\hline \multirow[t]{2}{*}{ NOISE } & Patras (Greece) & $\begin{array}{l}\text { Installation of soundproof windows on a pilot } \\
\text { exposed municipality building }\end{array}$ & Reduction of internal sound levels & - \\
\hline & Tripoli (Lebanon) & $\begin{array}{l}\text { Installation within the port area of: speed limit, no } \\
\text { honking, and cross road signs' speed bumps }\end{array}$ & Decrease of sound levels & Municipality of Tripoli \\
\hline \multirow[t]{2}{*}{ WATER } & Aqaba (Jordan) & $\begin{array}{l}\text { Continuous monitoring campaigns to constantly } \\
\text { evaluate and control water physical and } \\
\text { chemical properties. } \\
\text { Accord with the Aqaba Container Terminal in order to } \\
\text { limit, at best, dumping and spills in the sea }\end{array}$ & $\begin{array}{l}\text { In the Container Port of the Gulf of } \\
\text { Aqaba, water pollutant parameters } \\
\text { indicate good quality sea water. }\end{array}$ & $\begin{array}{l}\text { Aseeza, } \\
\mathrm{ACT}\end{array}$ \\
\hline & Tripoli (Lebanon) & $\begin{array}{l}\text { Collection and safely disposal of ships discharges. } \\
\text { Awareness Campaign } \\
\text { Cleaning campaign conducted to collect solid waste. } \\
\text { Purchase of equipment for oil spill } \\
\text { Elaboration of a Contingency Plan for Marine } \\
\text { Pollution Preparedness and Response for the } \\
\text { containment of oil spills and fire accidents. }\end{array}$ & $\begin{array}{l}\text { Slight increment of water quality } \\
\text { (long term results expected); } \\
\text { Emergency response team and } \\
\text { procedures; Establishment of an } \\
\text { Environmental port office. }\end{array}$ & $\begin{array}{l}\text { Municipality of Tripoli, } \\
\text { Council of reconstruction and } \\
\text { Development of Tripoli }\end{array}$ \\
\hline
\end{tabular}

. $\mathrm{PM}_{10}$ : Particulate matter with diameter $\leq 10 \mu \mathrm{m}$. ARPAL Liguria: Agenzia Regionale per la Protezione Ambientale (Regional Agency for the Environment Protection in Liguria 


\subsection{Administrative and Financial Management}

A strong management team has been involved in the implementation of all parts of the project as administrative aspects has been really challenging and very demanding.

Each partner has a project leader and a financial manager, coordinated by the Applicant and Financial Manager. In order to follow ENPI strict and complex regulations in terms of interim reports, budget shifts and procedures, continuous contact with partners was necessary, together with special sessions dedicated to management and financial issues during all plenary meetings.

The effort on management and administration has been really demanding, in terms of both human resources skills and number of hours dedicated to this activity. The ENPI JMA organized training sessions in all countries involved in the project (Italy, Jordan, Lebanon and Greece) in order to provide the necessary information.

For what concerns prefunding and funding schemes, JMA provides partners with an advance payment of around $20 \%-25 \%$ of the foreseen budget. In order to get a second pre-financing, the partnership needs to reach a threshold of at least $80 \%$ of the ENPI share of the eligible forecast and expenses incurred in the period; no fixed reporting periods are foreseen. Within this financing system, an adequate cash flow must be guaranteed by each partner by anticipating funds for current expenses, and are reimbursed after certification and reporting period. The MESP team, after receiving the advance payment at month 4 , requested a pre-financing on the second year, after a long procedure, receiving it at month 35 . These long processes reflected directly on activity, as the cash flow shortage could not always be overcome by some partners. During the second and third year, in particular, an accurate revision of spending planning and procedures for each partner was necessary in order to solve and break through any cash problem and avoid delays in pilot projects' interventions.

The budget in the ENPI project is strictly structured with a detailed split on cost item, calculated for unit cost (like in other Interreg programmes). This implies that incurred expenses must be very accurate and always need to refer to a specific budget line, with no room for errors or rounding. Budget shifts (minor and major) are always possible but need to follow a long procedure and, obviously, must be duly justified and motivated. The MESP partnership needed several adjustments within project lifetimes and asked for one major and three minor budget shifts.

As described, all administrative rules and procedures have been strict and very demanding in terms of human resources involved and work hours. The team worked very hard for the whole duration of the project, trying to be prepared before deadlines foreseen and breaking through difficulties, accomplishing all necessary steps and duties in a strong cooperative way.

\subsection{Communication and Dissemination}

At the Kick Off meeting, the MESP partnership settled an embryonal Communication Plan with the preliminary basic actions - website, visibility identity material, fact sheets, news - that have been implemented and developed within the whole duration of the project. In this way, new strategies could be developed case by case according to forthcoming needs and unexpected occasions.

Two International Workshops have been organized in Patras and Aqaba in order to disseminate MESP content and build bridges with local stakeholders and authorities. The Final Conference was held in Tripoli, 9 September 2015, in the Order of Engineers and Architects Conference Hall in order to have a targeted audience that could spread MESP content in the best way.

JMA organized several capitalization events that the MESP partnership took part in in Rome and Amman. These events gave the opportunity to spread MESP contents, outputs, network among other ENPI CBCMED projects and the crosscutting approach, and confront common emerging problems.

The same target has been achieved by participating in several conferences organized by ENPI CBCMED projects (CustomMED, MAPMED, MEDPORT, Gouv'airnance).

During the three years of the MESP duration, news has been published continuously on the website (www.mesp.org) and on Twitter (@MESPproject), avoiding newsletters, considered an old-fashioned form of communication. As shown in Figure 5, in two years, MESP reached the important 
goal of a spread and global diffusion throughout the whole world with a significant amount of visits in the USA, Russia, Italy and Lebanon (with, respectively, 5589, 2401, 1732 and 1254 visits).

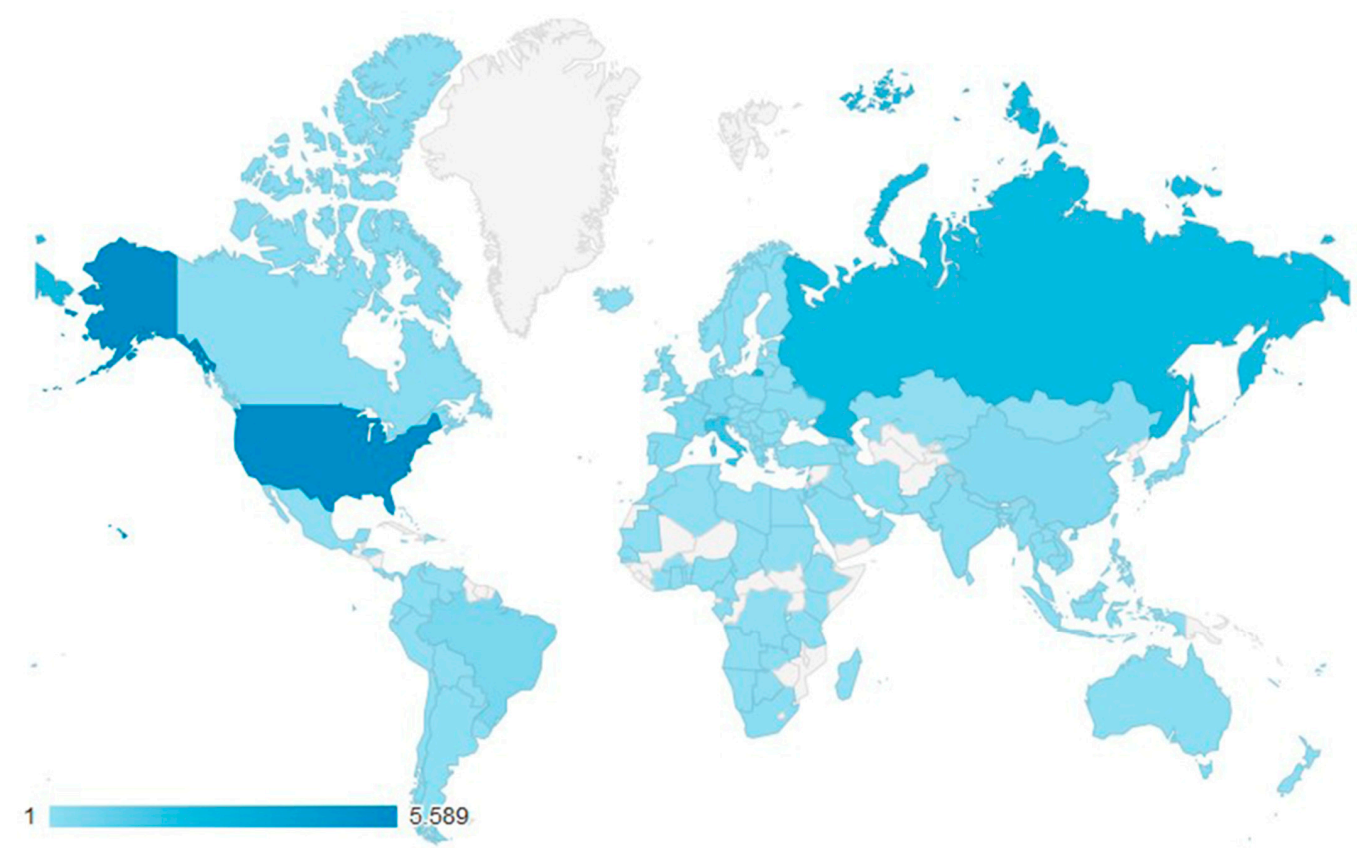

Figure 5. Geolocalisation of visits on the MESP website.

In order to strengthen the scientific value of the work done on the project, given the fact that academic institutions are in the partnership, important dissemination actions were devoted to the participation with international conferences and the submission of papers to international peer review journals.

\section{Outcomes and Lesson Learned}

After forty-two months of the project, the partnership attempt has been to analyze throughout the duration of the cooperation positive and critical aspects of MESP activities from different points of view. This was very important in order to capitalize and exploit what emerged from this common experience for further collaborations and for other institutions dealing with cooperative project on sustainability.

\subsection{Major Results Achieved and Strong Points}

The main positive outcomes of the project have been identified in four major fields, namely project activities, scientific results, impact on the territory and project management.

For what concerns results obtained on project activities, MESP succeeded in achieving the target goals foreseen. In particular, the main outcomes represented by the Guidelines for Port Environmental Management and the pilot project interventions in the four selected port areas (Aqaba, La Spezia, Patras and Tripoli) have been accomplished in a successful way. Therefore, MESP succeeded in formulating a common tool based on the elaboration of measurement methodologies and test procedures that can be easily replicated in other ports, especially in the Mediterranean basin, in order to ameliorate ports' sustainable environmental management and improve governance of ports in the three major environmental sectors of air, noise and water.

These activities have been achieved starting with a great effort on the initial knowledge exchange among the partnerships on pollution reduction issues This database has been performed by focusing on the related management tools, methodologies, tools, significant experiences and technologies, laws and standards and meaningful experiences and expertise (best practices). Thanks to the continuous debate 
within the partnership, by involving internal experts and external Scientific Advisory Committee members, it was possible to increase significantly the skills and competences of the whole partnership on sustainable environmental and pollution reduction. Because of this solid and active cooperation among partners, a reliable working group has been created with great results in collaboration.

Regarding scientific results, MESP partners submitted several scientific papers to international conferences and journals, thanks to the collaboration of the three different universities in the partnership with heterogeneous expertise from different Mediterranean areas and culture [14,29-31].

Important results have also been achieved on the direct impact of the project on the territory. By raising the awareness on sustainable environmental impact on air, noise and water pollution, and working since the beginning with local stakeholders in a participative approach, the enhancement of MESP partnership capability to work locally with port authorities and within partners' territories has been possible in order to ameliorate environmental management, survey and analysis. Moreover, some partners built strong collaborations, which led to formal agreements with Container Terminal companies and stakeholders, encountered during the implementation of pilot project activities, for a continued monitoring of environment quality in port areas.

The greatest impact on local territory is evident in the case of Tripoli, where, thanks to the great effort of the Port Authority, partner in the project, a new environmental working group has been established and a new environmental office has been built, being the starting point for a durable pollution abatement management in the area. The connection with local stakeholders has been further strengthened by the organization of dissemination activities as workshops and project meetings in each partner city related to MESP activities, leading to a continuous debate on the topic of environmental pollution. Some partners succeeded in building a long-lasting cooperation with local public administration, stakeholders, academic institutions and port authorities and raising awareness among ports workers.

From the project management point of view, all teams achieved building and improving capacities in project management, financial, administrative and technical issues related to decentralized cooperation projects, some of them being involved in their first experience in EU programmes. A strong coordination and communication by the Applicant was crucial in accomplishing projects achievements such as reports, monitoring campaigns, dissemination activities, pilot project interventions and organization of events.

MESP deliverables, tools and legacy are summarized in Table 2 in order to highlight the effectiveness assessment of the project.

\subsection{Barriers and Weak Points}

Within MESP project life, many barriers have been faced. In the following, and summarized in Table 3, major challenges will be described, as above, with regards to project activities, impact on the territory and project management.

Regarding project activities, the diversity of each port in terms of context, geographical location and boundaries, activities, operating equipment and vehicles did not represent a barrier but allowed MESP partnership to create and adopt a different approach for the build-up of the guideline document. In fact, it ensured a high level of replicability and adaptation to different port realities. Indeed, the obstacle was to keep a common methodological approach regardless of the differences and maintain the overall objective of the project throughout the implementation processes. Moreover, some restraints have been highlighted in the different approaches in tackling the cultural common routines of port workers and nearby populations. The difference in languages, especially during elaboration of common reports or guidelines, represented sometimes a challenge, a partnership being composed of people from four different countries: Italy, Lebanon, Greece and Jordan. 
Table 2. MESP (Managing the Environmental Sustainability of Ports for a durable development) main impact assessment.

\begin{tabular}{|c|c|}
\hline Tools & $\begin{array}{l}\text { - Existing pollution management in ports' best practices deep analysis and consequent knowledge exchange } \\
\text { Evaluation of common criteria and methodologies for the identification of a sustainable approach to the air, noise and water } \\
\text { pollution in ports to be easily applied and replicated in other Mediterranean ports } \\
\text { - Evaluation check of the above mentioned through Pilot intervention in MESP port areas }\end{array}$ \\
\hline Deliverables & $\begin{array}{l}\text { - "Roadmap on Sustainability Criteria: Guidelines for Port Environmental Management" document, in order to disseminate a } \\
\text { - } \quad \text { Pilot projects, in order to assess and demonstrate the reliability of the approach and methodologies }\end{array}$ \\
\hline Impacts & $\begin{array}{l}\text { - Scientific and technical knowledge exchange between the partnership } \\
\text { - } \quad \text { Awareness increase on pollution issues in ports carried out through communication and dissemination campaigns } \\
\text { - } \quad \text { Deep involvement of local authorities and private stakeholders } \\
\text { Environmental pollution levels decrease both in port and in surrounding urban areas due to the positive results of the } \\
\text { common pollution management methodologies drawn-up, highlighted by Pilot Projects (see Table 1) }\end{array}$ \\
\hline Legacy & $\begin{array}{l}\text { - Strong and durable networks both within the partnership and among partners and local stakeholders } \\
\text { - } \quad \text { Expertise scientific and technological transfer inside the MESP partnership } \\
\text { pollution issues } \\
\text { - Knowledge transfer to ports outside the project wanting to face, for the first time, the pollution issue in ports and replicate } \\
\text { MESP results through dissemination campaigns and the guideline document }\end{array}$ \\
\hline
\end{tabular}


Table 3. Contingency chart.

\begin{tabular}{|c|c|c|c|}
\hline \multirow{5}{*}{ Project Activities } & Challenges Encountered & Description of Level of Challenge & Contingency Plan \\
\hline & $\begin{array}{l}\text { Difficulties in the definition of a common } \\
\text { methodological approach }\end{array}$ & $\begin{array}{l}\text { High risk, since the common approach is crucial to } \\
\text { implement pilot activities }\end{array}$ & $\begin{array}{l}\text { Early and deep state-of-the-art analysis, frequent } \\
\text { checks and revisions of the various proposed } \\
\text { approaches on a cooperative solution. } \\
\text { Strong coordination and communication actions } \\
\text { by the applicant and the partners }\end{array}$ \\
\hline & $\begin{array}{l}\text { Difficulties in different languages } \\
\text { and cultures }\end{array}$ & Low risk & $\begin{array}{l}\text { Through the deep relationships started from the } \\
\text { beginning of this challenge to get to a strong point, } \\
\text { which enriched all of the partnerships. }\end{array}$ \\
\hline & Choice of the pollutant threshold & $\begin{array}{l}\text { High risk, as different laws and regulations in } \\
\text { partner countries' different standard limits foreseen }\end{array}$ & $\begin{array}{l}\text { Use of national limits where present and adoption } \\
\text { of EU or International regulation where lacking }\end{array}$ \\
\hline & $\begin{array}{l}\text { Difficulties in measurement campaign } \\
\text { and inadequate equipment }\end{array}$ & $\begin{array}{l}\text { High risk, due to the missing evaluation of pilot } \\
\text { project interventions }\end{array}$ & $\begin{array}{l}\text { Borrowing of some equipment from one partner } \\
\text { to another }\end{array}$ \\
\hline Impact & $\begin{array}{l}\text { Difficulties in collaborating with } \\
\text { local stakeholders }\end{array}$ & Medium risk & Tuning of planned pilot area \\
\hline \multirow[t]{3}{*}{ Management } & $\begin{array}{l}\text { Challenging Programme administrative } \\
\text { and financial procedures }\end{array}$ & High risk in undertaking duties & $\begin{array}{l}\text { More effort in } \mathrm{HR} \text { on financial and administrative } \\
\text { tasks; frequent training sessions and strong } \\
\text { management by the Coordinator }\end{array}$ \\
\hline & Lacking of cash flow & $\begin{array}{l}\text { High risk of impeding the implementation of the } \\
\text { project }\end{array}$ & $\begin{array}{l}\text { Partners' institutions needed to anticipate funds } \\
\text { in order to proceed with activities. }\end{array}$ \\
\hline & $\begin{array}{l}\text { Challenging templates, rules and } \\
\text { procedures from the Programme }\end{array}$ & $\begin{array}{l}\text { Medium risk, as they caused delays and errors in } \\
\text { the completion of the mandatory procedures }\end{array}$ & $\begin{array}{l}\text { A continued and strong coordination among } \\
\text { Applicants with Management Authorities and } \\
\text { project partnerships }\end{array}$ \\
\hline
\end{tabular}


Another difficulty faced at the beginning of the activity was the choice of the pollutant thresholds to follow as the different laws and regulations in partner countries foresee different standard limits for emissions in air, noise and water sectors. The partnership agreed-as explained in the Guidelines-on leaving national limits where they are at present and adopting European or International regulations where lacking. Regarding the weak points, during measurement campaigns, together with initial difficulties in getting permission for the implementation of measures of noise level inside the port areas from local authorities, the unavailability of appropriate equipment in the local market slowed down the whole process as for the purchase of modeling and simulation software.

With references to local impact on the territory, sometimes, as mentioned above, at different stages of the process, some partners faced barriers to working and collaborating with the different stakeholders, mainly with the port authorities. On one occasion, a pilot project foreseen in the first moment within the port boundaries has been focused on in a nearby urban area, affected by pollution coming from harbor activities.

From the project management point of view, it comes out that the ENPI CBC MED programme put pressure on administrative and financing issues more than technical ones, unexpectedly shifting more efforts of human resources to these matters. Moreover, within the four countries, different procedures in tackling administrative, procurement and financial matters have been found to contribute to slowing the initial phase of the MESP project.

Cash flow represented a challenge throughout the whole duration of the project. In the ENPI CBC MED programme, as in most of the European ones, funds are anticipated only in a small part (around $20 \%$ ) and are paid back after reporting periods. This system generates cash flow problems, as most of the expenses need to be anticipated by each structure involved, getting reimbursed only after the revision of whole declared expenses. Some of the partners, at their first European cooperation project experience, found difficulties in justifying this cash flow lack with their own administration, in the continuous need for cash to face expenses related to ongoing activities.

Within the whole duration of the project, the Joint Management Authority changed templates and reporting procedures several times, causing a deep lack in information available (only one training course in three years in each country), as well as delays and errors in the completion of the procedures.

In addition, strict ENPI financial regulations on expenditures, bureaucracy and budget shift claims, created barriers and difficult situations, such as a lack of understanding in the partnership together with delays in reporting. These challenges, in addition to slow, different and difficult internal bidding procedures for some partners, induced additional stalls for the whole implementation period.

All these abovementioned challenges were overcome through continued coordinating and arrangements among Management Authorities, Coordinator and partnership, while a strong communication and knowledge exchange facilitated many issues in the administrative and financial processes.

\section{Conclusions}

At the end of the project, looking back at three years of work, several best practices and lessons learnt during the implementation of the activities can be identified. Other partnerships involved in international cooperation aiming for environmental sustainability can capitalize on them in order to facilitate their activities and foster reciprocal collaboration. Furthermore, the delivery of practicable guidelines and the development of a common regulatory approach focusing on water, air and noise are an effective outcome of the project.

First of all, MESP created a strong network among local authorities, public administration, stakeholder and universities, producing in each context the correct approach for a durable development of pollution management. To this extent, academic institutions played a major role in bringing support and know-how in the partnership. MESP project succeeded, through this inclusive approach, in promoting environmental sustainability at the Mediterranean level, suggesting efficient mitigation actions in protecting nearby urban areas from the impact of port activities, improving the quality of life 
of port workers and safeguarding the biodiversity in harbors. However, it should be underlined that all technical and scientific results are a strict consequence of the networking among partners, public administrations, private stakeholders, and research institutions, which was the prerequisite for every successful action on the field.

Good practices in air, noise and water sectors were identified to help management authorities of ports reach a higher level of sustainability and reduce environmental pollution, as clearly explained in the Guidelines document. Furthermore, the project started new processes of environmental monitoring that are becoming a permanent fixture in the environmental management of involved harbors. Environmental pollution levels in ports were evaluated, impact of port activities on urban surroundings was analyzed and assessed, and interventions to reduce pollution were recommended, leading to the enrichment of all ports through the exchange of expertise, practices and knowledge. In this regard, the workshops and events organized during MESP played a relevant role. Their implementation involved all target stakeholders and the accurate communication succeeded in bringing awareness to the participants about the relevance of the environmental management of ports for achieving a durable development.

Lessons learnt over the project dealt with several features, ranging from the effect of recovery actions to the impact of funds' timing. In relation to this, the distribution over time of financing and the administrative procedures needed to obtain the reimbursement of incurred expenses were revealed to be a real obstacle to the implementation of the expected activities. The risk to fail in developing the foreseen actions for a leak of money caused by delays in the administration process was largely underestimated by the present partnership at the beginning of the project. On the contrary, it has been a threat to the regular implementation of the tasks over its whole duration.

Concerning the technical aspects, the MESP partnership observed the relevance to create, for an effective pollution abatement strategy, a common database on port characteristics, procedures and figures, together with methodologies, equipment and operating systems. Moreover, the importance of developing a multidisciplinary approach was noticed, aiming to highlight the interconnections among pollution types and to obtain multi-effect results with one intervention.

Finally, the importance of cooperation among countries in deciding and implementing initiatives for sustainability in coastal areas, where the EU cooperation policy, and specifically the ENPI CBC MED programme, plays a crucial role in fostering and facilitating must be made evident one more time. On a local scale, communication and coordination among port authorities, municipalities, private stakeholders, and research institutions are essential for ensuring environmental sustainability in harbors, while port networking significantly helps to enhance the impact of the achieved results. In the same way, dissemination through scientific papers, public events, workshops, media and social media is an essential tool to capitalize projects' results.

Acknowledgments: This publication has been produced with the financial assistance of the European Union under the European Neighborhood and Partnership Instrument Cross-Border Cooperation Mediterranean Sea Basin Programme (ENPI CBC MED). The contents of this document are the sole responsibility of the authors and can under no circumstances be regarded as reflecting the position of the European Union or of the Programme's management structures. The MESP project's total budget is $€ 1,388,695.72$, and it was financed for an amount of $€ 1,249,826.15(90 \%)$ by the European Union.

Author Contributions: Authors from UNIGE (Corrado Schenone, Margherita Marrè Brunenghi and Ilaria Pittaluga) have been in charge of the management and the writing of the draft of the manuscript, in particularly in general paragraphs. MSS (Mohammed Rasheed and Riyad Manasrah), LSPA (Federica Montaresi and Lorenzo Montani), MUT (Walid Kamali, Abdallah Abdul Wahab and Yara El Moghrabi) and OEPT (Abdelrahman Hajar and Dima Merhaby) authors contributed both to the research and the manuscript regarding the pilot project interventions and related results, information and deliverables within the specific sectors as in Figure 2.

Conflicts of Interest: The authors declare no conflicts of interest. 


\section{References}

1. Commission of the European Communities. Communication from the Commission to the European Parliament, the Council, the European Economic and Social Committee and the Committee of the Regions. Mainstreaming Sustainable Development into EU Policies: 2009 Review of the European Union Strategy for Sustainable Development. COM (2009) 400 Final; Commission of the European Communities: Brussel, Belgium, 2009.

2. Eurostat. Sustainable Development in the European Union. 2015 Monitoring Report of the EU Sustainable Development Strategy; Publications Office of the European Union: Luxembourg, 2015.

3. Pavasovic, A. The Mediterranean Action Plan Phase II and the revised Barcelona Convention: New prospective for integrated coastal management in the Mediterranean region. Ocean Coast Manag. 1996, 31, 133-182. [CrossRef]

4. Frazão Santos, C.; Domingos, T.; Ferreira, M.A.; Orbach, M.; Andrade, F. How sustainable is sustainable marine spatial planning? Part I-Linking the concepts. Mar. Policy 2014, 49, 59-65.

5. Meiner, A. Integrated maritime policy for the European Union-Consolidating coastal and marine information to support maritime spatial planning. J Coast Conserv. 2010, 14, 1-11. [CrossRef]

6. Chapin, F.S.; Carpenter, S.R.; Kofinas, G.P.; Folke, C.; Abel, N.; Clark, W.C.; Olsson, P.; Smith, D.M.; Walker, B.; Young, O.R.; et al. Ecosystem stewardship: Sustainability strategies for a rapidly changing planet. Trends Ecol. Evol. 2010, 25, 241-249. [CrossRef] [PubMed]

7. Douvere, F. The importance of marine spatial planning in advancing ecosystem-based sea use management. Mar. Policy 2008, 32, 762-771. [CrossRef]

8. European Commission. An Integrated Maritime Policy for the European Union. Brussels: Communication from the Commission, 575 Final; European Commission: Brussel, Belgium, 2007; p. 16.

9. European Commission. Commission Implementing Decision of 12.3.2012 Concerning the Adoption of the Integrated Maritime Policy Work Programme for 2011 and 2012. C (2012) 1447 Final; European Commission: Brussels, Belgium, 2012.

10. European Commission. Directive 2008/56/EC of the European Parliament and of the Council of 17 June 2008, Establishing a Framework for Community Action in the Field of Marine Environmental Policy (Marine Strategy Framework Directive); Publications Office of the European Union: Luxembourg, 2008; pp. 19-40.

11. European Commission. Blue Growth. Opportunities for Marine and Maritime Sustainable Growth. Communication from the Commission to the European Parliament, the Council, the European Economic and Social Committee and the Committee of the Regions. COM (2012) 494 Final; Publications Office of the European Union: Luxembourg, 2012.

12. Gilbert, A.J.; Alexander, K.; Sardá, R.; Brazinskaite, R.; Fischer, C.; Gee, K.; Jessopp, M.; Kershaw, P.; Los, H.J.; March Morla, D.; et al. Marine spatial planning and Good Environmental Status: A perspective on spatial and temporal dimensions. Ecol. Soc. 2015, 20. [CrossRef]

13. The Council of the European Union. 2010/631/EU: Council Decision of 13 September 2010 Concerning the Conclusion, on Behalf of the European Union, of the Protocol on Integrated Coastal Zone Management in the Mediterranean to the Convention for the Protection of the Marine Environment and the Coastal Region of the Mediterranean; Publications Office of the European Union: Luxembourg, 2010.

14. Schenone, C.; Pittaluga, I.; Repetto, S.; Borelli, D. Noise pollution management in ports: A brief review and the EU MESP project experience. In Proceedings of the 21st International Congress on Sound and Vibration, Beijing, China, 13-17 July 2014.

15. Puig, M.; Wooldridge, C.; Casal, J.; Darbra, R.M. Environmental reporting and communication-Show me the evidence! In Proceedings of the GreenPort Congress, Antwerp, Belgium, 9-10 October 2013.

16. Trozzi, C.; Vaccaro, R. Air pollutant emissions estimate from global ship traffic in port and in cruise: Methodology and case study. In Proceedings of the 11th International Scientific Symposium “Transport and Air Pollution", Graz, Austria, 19-21 June 2002.

17. Battistelli, L.; Coppola, T.; Fantauzzi, M.; Quaranta, F. A case study on the environmental impact of harbour activities: Analysis and solutions. In Proceedings of the 1st International Symposium on Naval Architecture and Maritime, Istanbul, Turkey, 23-24 October 2011.

18. Badino, A.; Borelli, D.; Gaggero, T.; Rizzuto, E.; Schenone, C. Normative framework for noise emissions from ships: Present situation and future trends. In Proceedings of the 3rd International Conference on Marine Structures MARSTRUCT, Hamburg, Germany, 28-30 March 2011. 
19. Badino, A.; Borelli, D.; Gaggero, T.; Rizzuto, E.; Schenone, C. Analysis of airborne noise emitted from ships. In Proceedings of the 14th International Congress of the International Maritime Association of the Mediterranean, IMAM, Genova, Italy, 13-16 September 2011.

20. Badino, A.; Borelli, D.; Gaggero, T.; Rizzuto, E.; Schenone, C. Acoustic impact of ships: Noise-related needs, quantification and justification. In Proceedings of the 14th International Congress of the International Maritime Association of the Mediterranean, IMAM, Genova, Italy, 13-16 September 2011.

21. Badino, A.; Borelli, D.; Gaggero, T.; Rizzuto, E.; Schenone, C. Normative framework for ship noise: Present situation and future trends. Noise Control Eng. J. 2012, 60, 740-762. [CrossRef]

22. Badino, A.; Borelli, D.; Gaggero, T.; Rizzuto, E.; Schenone, C. Acoustical impact of the ship source. In Proceedings of the 21st International Congress on Sound and Vibration, Beijing, China, 13-17 July 2014.

23. Borelli, D.; Gaggero, T.; Rizzuto, E.; Schenone, C. Measurements of airborne noise emitted by a ship at quay. In Proceedings of the 22nd International Congress on Sound and Vibration, Florence, Italy, 12-16 July 2015.

24. Badino, A.; Borelli, D.; Gaggero, T.; Rizzuto, E.; Schenone, C. Airborne noise emissions from ships: Experimental characterization of the source and propagation over land. Appl. Acoust. 2016, 104, 158-171. [CrossRef]

25. Badino, A.; Borelli, D.; Gaggero, T.; Rizzuto, E.; Schenone, C. Noise Emitted from Ships: Impact Inside and Outside the Vessels. Procedia Soc. Behav. Sci. 2012, 48, 868-879. [CrossRef]

26. Rasheed, M.; Al-Trabeen, K.; Badran, M. Long-Term Water Quality Monitoring at an Industrial Site on the Northern Gulf of Aqaba, Red Sea. Mediterr. Mar. Sci. 2012, 13, 250-258. [CrossRef]

27. Rasheed, M.; Mian, S.; Aubrey, D. Guidelines for EIA of fish and shrimp hatcheries in a semi-enclosed water body. Ocean Coast Manag. 2011, 54, 678-686. [CrossRef]

28. Al-Tarabeen, M.; Hassan Aly, A.; Perez Hemphill, C.F.; Rasheed, M.; Wray, V.; Proksch, P. New nitrogenous compounds from a Red Sea sponge from the Gulf of Aqaba. Z. Naturforsch 2015, 70, 75-78.

29. Pittaluga, I.; Schenone, C.; Borelli, D. Pollution management and environmental sustainability of harbours: The MESP project. In Proceedings of the 50th ISOCARP International Planning Congress, Gdynia, Poland, 23-26 September 2014.

30. Kamali, W.; Wahab, A.A.; El Moghrabi, Y.; Kabbara, H.; Hajar, A.; Mecsaci, R.; Merhaby, D. Survey on Environmental Noise in the Port of Tripoli. In Proceedings of the 21st International Congress on Sound and Vibration, Beijing, China, 13-17 July 2014.

31. Kamali, W.; El Moghrabi, Y.; Wahab, A.A. Noise mitigation measures of noise intense activities in harbor area and surrounding. In Proceedings of the 22nd International Congress on Sound and Vibration, Florence, Italy, 12-16 July 2015.

32. Schenone, C.; Pittaluga, I.; Borelli, D.; Kamali, W.; El Moghrabi, Y. The impact of environmental noise generated from ports: Outcome of MESP project. Noise Map. 2016, 3, 1-11.

33. Roadmap on Sustainability Criteria: Guidelines for Port Environmental Management. Available online: http:/ / www.mesp.org/wp-content/uploads/2014/12/Guidelines.pdf (accessed on 27 September 2016).

34. Bryde, D.J. Modelling project management performance. Int. J. Qual. Reliab. Manag. 2003, 20, $229-254$. [CrossRef]

35. Lauras, M.; Marques, G.; Gourc, D. Towards a multi-dimensional project Performance Measurement System. Decis. Support Syst. 2010, 48, 342-353. [CrossRef]

36. Lindhard, S.; Larsen, J.K. Identifying the key process factors affecting project performance. Eng. Construct. Arch. Manag. 2016, 23, 657-673. [CrossRef]

37. ISO 9001:2015—Quality Management Systems—Requirements. Available online: http://www.iso.org/iso/ catalogue_detail?csnumber=62085 (accessed on 10 January 2017).

38. ISO 14001:2015-Environmental Management Systems—Requirements with Guidance for Use. Available online: http:/ / www.iso.org/iso/catalogue_detail?csnumber=60857 (accessed on 10 January 2017).

(C) 2017 by the authors; licensee MDPI, Basel, Switzerland. This article is an open access article distributed under the terms and conditions of the Creative Commons Attribution (CC-BY) license (http://creativecommons.org/licenses/by/4.0/). 